\title{
RESPONSE OF LITHUANIAN WINTER WHEAT ADVANCED LINES TO COMMON BUNT (Tilletia tritici (BJERK.) WINT)
}

\author{
Vytautas Ruzgas and Žilvinas Liatukas \\ Lithuanian Institute of Agriculture, Akademija, Kedainiai district, LT-58344, LITHUANIA \\ E-mail: liatukas@Izi.It
}

Communicated by İzaks Rašals

\begin{abstract}
The study was carried out at the Lithuanian Institute of Agriculture in an artificially inoculated nursery during 2006-2007. Resistance to common bunt in 2006 was tested for 71, in 2007 for 118 breeding lines of Lithuanian winter wheat from the competitive trial nursery. Additionally, 148 promising lines were selected and tested from the check nursery, which possessed some resistance in their pedigree ancestors. The average disease incidence in 2006 and 2007 was 80.9 and $63.5 \%$, respectively. The very high infection level highlighted the genotypes with the most effective resistance under conditions highly favourable for common bunt. There were no lines without infected ears. Among the 29 breeding lines tested in the two years, two lines Bill/Aspirant and Dream/Lut.9329 were infected the least, $17.2 \%$ and $1.9 \%$ in 2006 and $18.5 \%$ and $7.8 \%$ in 2007 , respectively. Most of the breeding lines were highly susceptible. Lines with disease incidence over $50 \%$ accounted for over $90 \%$ in 2006 and $80 \%$ in 2007 of the total lines tested. The most resistant lines had in their pedigrees the following resistance sources: genotypes Bill, Lut.9329, Strumok, Lut.9313, Lut.9358, Tommi as well as Dream, Haldor, 91002G2.1, 96/101, Bezenchiukskaya380.
\end{abstract}

Key words: wheat, breeding lines, cultivars, common bunt, resistance, organic agriculture.

\section{INTRODUCTION}

Common bunt (Tilletia tritici (Bjerk.) Wint) is a widely spread and potentially harmful disease of wheat all over the world. However, due to the high efficacy of synthetic seed treatment pesticides, breeding for resistance has been disregarded for a long time. As a result, many European cultivars are susceptible to common bunt (Bonman et al., 2006; Dumalasova and Bartoš, 2006a; 2006b; Vanova et al., 2006). Moreover, experimental evidence regarding common bunt resistance of the newest winter wheat cultivars and breeding lines is very limited.

The area under organic agricultural production is steadily increasing in the EU. Common bunt is the main constraint for successful growing of organic winter wheat due to a very limited number of resistant cultivars. The main problem for organic seed producers is that organically produced seeds have to fulfil the same phytosanitary requirements as those of conventional origin. Biological control agents (for example Tillecur) as well as physical treatments cannot meet the demands of the guidelines reliably (Borgen and Davanlou, 2000; Jahn et al., 2004). Consequently, due to the high deficiency of certified organic seed, repeated cultivation of winter wheat with farm-saved seeds may in the short term lead to high infection with common bunt. In addition to loss of grain yield, bunt reduces grain quality be- cause it imparts a fishy odour to wheat grain and its products. Cultivation of resistant cultivars may be an effective way to meet the restrictions. Recent investigations about the quantity of resistance genes and their effectiveness suggest good possibilities for successful resistance breeding (Martynov et al., 2004; Petrenkova et al., 2005; Bonman et al., 2006).

The objective of this study was to evaluate Lithuanian winter wheat advanced breeding lines and their ancestors for $T$. tritici resistance.

\section{MATERIAL AND METHODS}

The experiments were carried out during 2005-2006 at the Lithuanian Institute of Agriculture (LIA) in an artificially inoculated nursery. The material subjected to bunt resistance tests included advanced breeding lines developed by conventional breeding methods and their ancestors. Breeding lines from the competitive trial nursery were grown in $17 \mathrm{~m}^{2}$ plots and replicated four times and the lines from the check nursery in non-replicated $7.5 \mathrm{~m}^{2}$ plots. Inoculation was carried out by shaking seeds with teliospores $(5 \mathrm{~g}$ spores/1,000 g seeds) in a flask for 5 minutes. In October, when the soil temperature was below $10{ }^{\circ} \mathrm{C}$ (as recommended by Gaudet and Puchalski, 1990; Johnson, 1992; 
Gaudet et al., 1994), the inoculated seeds of the lines from the competitive trial nursery (CTN) and cultivars were sown $15 \mathrm{~g}$ per genotype per $3 \mathrm{~m}$ length row at a depth of $7-10 \mathrm{~cm}$ in four replications situated in different parts of the field. The lines from the check nursery $(\mathrm{CN})$ were sown in one replication. Four counts were done for the check nursery lines in one replication. The disease incidence was measured for harvest of 100 heads at medium milk development stage (BBCH 75) as the proportion of infected ears from the total ear number harvested. The following scale was used to estimate varietal resistance: infected ears $0.0=$ very resistant, $0.1-5.0=$ resistant, 5.1-10.0 = moderately resistant, 10.1-30.0 = moderately susceptible, 30.1-50.0 = susceptible, $50.1-100.0$ = very susceptible (Szunics, 1990; Veisz et al., 2000). Statistical analysis was conducted by calculation of the mean and its standard devastation (SD).

\section{RESULTS}

The experimental years were very favourable for common bunt resistance screening. The total mean disease incidence in the nursery was 80.9 and $63.5 \%$ in 2006 and 2007, respectively. Infection was lower in 2007 due to a higher per cent of resistant genotypes in the nursery. Low infection in- cidence highlighted the lines with resistance under conditions favourable for common bunt.

In the two years, among 29 lines tested from the CTN, seven lines had an incidence lower than $50 \%$ at least in one year (Table 1). The least affected were lines Bill/Aspirant (17.2\% and 1.9\%), as well as Dream/Lut.9329 (18.5\% and $7.8 \%$ ), in 2006 and 2007, respectively. The other five lines expressed some resistance, but the infection level in 2006 was too high (up to $95.8 \%$ ) for their practical use.

The results of the test with the lines of CTN in 2006 are summarized in Table 2. None of the lines were infected less than 10\%. The lines Bill/Aspirant, Dream/Lut.9329 (2 lines) and Flair/Lut.9329 were infected up to $30 \%$ and were characterised as moderately susceptible. Two other lines from cross Bill/Aspirant were infected up to $50 \%$ and were characterised as susceptible. The other lines (65 or $91.6 \%$ ) were very susceptible with disease incidence over $50 \%$.

The response of the lines of CTN in 2007 is presented in Table 3. The lines Bill/Aspirant and Strumok/Lut.9329 were infected up to $5 \%$ and were characterised as resistant. The lines Dream/Lut.9329 and Strumok/Lut.9313 were

Table 1

THE RESPONSE TO COMMON BUNT IN BREEDING LINES FROM THE COMPETITIVE TRIAL NURSERY DURING 2006-2007

\begin{tabular}{|c|c|c|c|c|}
\hline \multirow{3}{*}{ Breeding line } & \multicolumn{4}{|c|}{ Infection, $\%$} \\
\hline & \multicolumn{2}{|c|}{2006} & \multicolumn{2}{|c|}{2007} \\
\hline & average $\pm \mathrm{SD}$ & range & average $\pm \mathrm{SD}$ & range \\
\hline Flair/Lut.96-2 & $91.3 \pm 4.6$ & $88-98$ & $56.5 \pm 6.0$ & $49-63$ \\
\hline Elena/Lut.956 & $95.3 \pm 4.1$ & $90-100$ & $88.0 \pm 4.2$ & $83-92$ \\
\hline Flair/Lut.9329 & $62.0 \pm 18.1$ & $39-80$ & $28.5 \pm 6.8$ & $19-35$ \\
\hline Flair/Lut.396 & $74.3 \pm 4.4$ & $70-80$ & $62.5 \pm 12.1$ & $50-79$ \\
\hline Flair/Lut.9365 & $94.5 \pm 2.9$ & $91-98$ & $55.0 \pm 5.0$ & $49-60$ \\
\hline Flair/Lut.9329 & $92.3 \pm 6.3$ & $85-100$ & $39.8 \pm 13.9$ & $28-58$ \\
\hline Astron/Tarso//Previa & $93.3 \pm 3.5$ & $89-97$ & $93.3 \pm 4.0$ & $90-98$ \\
\hline Astron/Tarso//Mobil & $90.0 \pm 6.1$ & $81-95$ & $94.0 \pm 3.9$ & $90-99$ \\
\hline Astron/Tarso//Yacht & $96.3 \pm 1.3$ & $95-98$ & $90.0 \pm 6.4$ & $81-96$ \\
\hline Hussar/Konsul A//Lut.96-6 & $88.0 \pm 2.2$ & $85-90$ & $77.0 \pm 7.8$ & $70-86$ \\
\hline Rostovchanka/Lut.96-3 & $93.3 \pm 2.4$ & $90-95$ & $68.5 \pm 15.5$ & $46-81$ \\
\hline Lut.96-3/Bold & $70.7 \pm 22.9$ & $37-88$ & $38.3 \pm 10.3$ & $28-49$ \\
\hline Rostovchanka/Chvilia & $78.6 \pm 5.4$ & $73-86$ & $65.5 \pm 4.5$ & $60-71$ \\
\hline Rostovcanka/Sj965210 & $94.5 \pm 1.3$ & $93-96$ & $80.5 \pm 8.4$ & $70-89$ \\
\hline Astron/Tarso//Miron.32 & $88.4 \pm 4.5$ & $84-94$ & $87.5 \pm 3.0$ & $85-91$ \\
\hline Pegassos/Dream & $90.0 \pm 4.1$ & $84-93$ & $43.8 \pm 10.2$ & $29-51$ \\
\hline Pegassos/Aspirant & $95.8 \pm 2.6$ & $92-98$ & $76.8 \pm 5.3$ & $71-83$ \\
\hline Pegassos/Aspirant & $92.8 \pm 3.1$ & $90-97$ & $88.3 \pm 8.0$ & $78-95$ \\
\hline Pegassos/Aspirant & $89.0 \pm 1.8$ & $87-91$ & $90.5 \pm 8.1$ & $79-97$ \\
\hline Biscay/Pesma & $94.3 \pm 4.9$ & $90-99$ & $76.3 \pm 7.0$ & $68-85$ \\
\hline Biscay/Dream & $96.5 \pm 0.6$ & $96-97$ & $53.0 \pm 17.9$ & $31-74$ \\
\hline Bill/Aspirant & $17.2 \pm 15.5$ & $2-35$ & $1.9 \pm 1.7$ & $0-4$ \\
\hline Pegasos/Residence & $97.3 \pm 3.6$ & $92-100$ & $79.0 \pm 22.2$ & $48-95$ \\
\hline Pegasos/Residence & $97.8 \pm 2.6$ & $94-100$ & $94.3 \pm 7.0$ & $84-99$ \\
\hline Pegasos/Biscay & $89.7 \pm 7.1$ & $80-96$ & $83.8 \pm 5.4$ & $78-91$ \\
\hline Pegasos/Biscay & $93.0 \pm 2.3$ & $91-96$ & $88.8 \pm 5.1$ & $83-95$ \\
\hline Pegasos/Biscay & $95.5 \pm 2.1$ & $93-98$ & $83.5 \pm 6.5$ & $79-93$ \\
\hline Dream/Lut.9329 & $95.8 \pm 1.0$ & $95-97$ & $47.3 \pm 4.9$ & $40-51$ \\
\hline Dream/Lut.9329 & $18.5 \pm 19.0$ & $2-40$ & $7.8 \pm 3.2$ & $3-10$ \\
\hline Average & 85.0 & & 66.9 & \\
\hline
\end{tabular}


INFECTION LEVEL OF COMPETITIVE TRIAL NURSERY'S LINES CLASSIFIED IN COMMON BUNT RESISTANCE GROUPS IN 2006

\begin{tabular}{|c|c|c|}
\hline Infection level, \% & Lines & Number of lines \\
\hline $10.1-30.0$ & Bill/Aspirant, Dream/Lut.9329 (2)*, Flair/Lut 9329 & $4(5.6 \%)$ \\
\hline $30.1-50.0$ & Bill/Aspirant (2) & $2(2.8 \%)$ \\
\hline $50.1-100.0$ & $\begin{array}{l}\text { Astron/Manef, Astron/Tarso//Mobil, Astron/Tarso//Previa, Astron/Tarso//Yacht, Astron/Tarso//Miron.32, } \\
\text { Belisar/Briz, Bill/Aspirant, Biscay/Dream (3), Biscay/Pesma (2), Bussard/OL95-1, Dream/Asketis (2), Dream/Aspi- } \\
\text { rant, Dream/Lut.9329 (3), Dream/Pesma (2), Elena/Lut 956, Flair/Lut 3-96 (4), Flair/Lut 9-365 (2), Flair/Lut 9-329 } \\
\text { (2), Flair/Lut 96-2 (2), Hussar/Konsul A//Bussard, Hussar/Konsul A//Lut.96-6 (2), Hussar/Konsul A//Previa, } \\
\text { Lars/Lut.96-3, Lone/Inna//Lut.96-2, Lut 96-3/Bold, Marabu/Flair, Miron.61/Batis, Pegasos/Aspirant (3), } \\
\text { Pegasos/Biscay (5), Pegasos/Dream, Pegasos/Lut.9328, Pegasos/Pesma, Pegasos/Residence (2), Rector/Briz, } \\
\text { Rostovchanka/Sj965210, Rostovchanka/Chvilia, Rostovchanka/Flair, Rostovchanka/Lars, Rostovchanka/Lut 96-3, } \\
\text { Rufa/Elena, Rufa/Lut.96-10, Rufa//Contra/Astron, Širvinta 1/A 940145, Širvinta1/Batis }\end{array}$ & $65(91.6 \%)$ \\
\hline & Infection average & $84.0 \%$ \\
\hline
\end{tabular}

* Number in brackets means how many lines with the same pedigree were tested.

Table 3

INFECTION LEVEL OF COMPETITIVE TRIAL NURSERY'S LINES CLASSIFIED IN COMMON BUNT RESISTANCE GROUPS IN 2007

\begin{tabular}{|c|c|c|}
\hline Infection level, \% & Lines & Number of lines \\
\hline $0.1-5.0$ & Bill/Aspirant, Strumok/Lut.9392, & $2(0.8 \%)$ \\
\hline $5.1-10.0$ & Dream/Lut.9329, Strumok/Lut.9313, & $2(0.8 \%)$ \\
\hline $10.1-30.0$ & $\begin{array}{l}\text { Dream/Pesma (2)*, Flair/Bill, Flair/Haldor, Maverich/Savannah, Mironovskaya32/Soissons, Olivin/Cubus, } \\
\text { Zolotava/Lut.9358, }\end{array}$ & $8(6.8 \%)$ \\
\hline $30.1-50.0$ & $\begin{array}{l}\text { Biscay/ Dream, Dream/Lut.9329, Dream/Pesma, Flair/Lut.9329 (2), Lut.96-3/Bold, Maverich/Savannah, } \\
\text { Pegassos/Dream, Zolotava/Mironovskaya Ostistaya. }\end{array}$ & $9(7.6 \%)$ \\
\hline $50.1-100.0$ & $\begin{array}{l}\text { Astron/Lut.96-3 (2), Astron/Manef, Astron/Tarso//Mobil, Astron/Tarso//Previa, Astron/Tarso//Ukrainka } \\
\text { Odesskaya, Astron/Tarso//Yacht, Astron/Tarso//Mironovskaya32, Biscay/Dream (2), Astron/3/BEZ2B/CGN//VR2, } \\
\text { Briz//Belisar/Briz, Dirigent/Cortez (4), Dream/Pesma (3), Elena/Lut.956, Flair/96.101, Flair/Ansgar, Flair/Haldor, } \\
\text { Flair/Kris (2), Flair/Lut.3-96, Flair/Lut.9329, Flair/Lut.9365, Flair/Lut.9392, Flair/Lut.96-2, Flair/Maverich, } \\
\text { Flair/Pentium, Flair/Ukrainka Odesskaya, Hussar/Konsul A//Lut.96-6, Lone/Inna//Hereward, Lone/Inna//Lut.96-2 } \\
\text { (4), Lone/Inna//Lut.96-6 (2), Marabu/Alma, Marabu//Hussar/Konsul A (2), Maverich/CB9303, Maverich/Lut.9321, } \\
\text { Maverich/Lut. 9358, Mironovskaya61/Lut.9328, Mironovskaya61/BUL.63131, Mironovskaya61/WTPT128WM, } \\
\text { MV0695/Aspirant, Olivin/Aspirant (3), Olivin/Cubus, Pegassos/Aspirant (3), Pegassos/Biscay (3), } \\
\text { Pegassos/BUL.661.2, Pegasos/Lut.96-3 (2), Pegassos/Lut.96-6 (2), Pegassos/Lut.261.66, Pegassos/Nika Kubani, } \\
\text { Pegassos/Residence (2), Rostovcanka/Sj965210, Rostovcanka/Chvilia, Rostovchanka/Lut.96-3, Rostovchanka/Ebi } \\
\text { (3), Belisar/Rufa (2), Rostovchanka/Bold (3), STH1096/Bussard, Rostovchanka/Belisar (4), Tarso/Lut.9358, } \\
\text { Rostovchanka/Flair (4), Zentos/Lut.97-4, Zolotava/Lut.9358 (3), Zolotava/Mironovskaya Ostistaya }\end{array}$ & $97(84 \%)$ \\
\hline & Average infection & 69.7 \\
\hline
\end{tabular}

* Number in brackets means how many lines with the same pedigree were tested.

damaged up to $10 \%$. Eight or $6.8 \%$ of the lines were infected up to $30 \%$. The number of lines infected up to $50 \%$ was 9 or $7.6 \%$. The other lines (97 or $84 \%$ ) were very susceptible.

Results of the lines of $\mathrm{CN}$ testing revealed that there were no completely resistant lines (Table 4). The lines 91002G2.1/Lasta, Strumok/Lut.9392, and Tarso/Bussard were characterised as moderately resistant and showing damage up to $10 \%$. Moderately susceptible were 8 or $5.4 \%$ of lines. Seventeen lines possessed some resistance. The greater part of lines (120), or $81.1 \%$, were very susceptible.

Table 5 shows the resistance of ancestors of the least damaged lines. Screening of winter wheat germplasm for resistance to $T$. tritici showed a range in variation from 2.4 to $87.4 \%$. However, none of the cultivars were characterised as resistant in all testing years. The lowest infection during the two years of testing was in ancestors Tommi, Lut.9358, Lut.9313, Bill, Cubus, Solist, Dream, and 91002G2.1. These genotypes were characterised by maximal disease level (15.0-25.3\%) as moderately susceptible.

\section{DISCUSSION}

The lines produced from crosses Bill/Aspirant, Flair/Bill, Bussard/Purdue4930//Bill inherited resistance to common bunt from Bill (infection 17.2\% in 2006), since cultivars Aspirants, Flair, Bussard, Purdue 4930 were very susceptible (infection over 50\%). Lines from crosses Bill/Dream, Dream/Bill, 91002G2.1/Bill might have inherited resistance from both parents, as both ancestors were in the same resistance group (up to 30\%). It is likely that these lines inherited resistance from one parent or that both parents pos- 
INFECTION LEVEL OF THE CHECK TRIAL NURSERY'S LINES WITH PROMISING RESISTANCE SOURCES IN PEDIGREE CLASSIFIED IN COMMON BUNT RESISTANCE GROUPS IN 2007

\begin{tabular}{|c|c|c|}
\hline Infection level, \% & Lines & Number of lines \\
\hline $5.1-10.0$ & 91002G2.1/Lasta, Strumok/Lut.9392, Tarso/Bussard & $3(2 \%)$ \\
\hline $10.1-30.0$ & $\begin{array}{l}\text { Bill/Dream, Dream/Bill (2)*, Dream/Lut.9329, Flair/Lut.9392, Maverich/Savannah, Residence/Tommy, } \\
\text { Strumok/Lut.9329 }\end{array}$ & $\begin{array}{c}8 \\
(5.4 \%)\end{array}$ \\
\hline $30.1-50.0$ & $\begin{array}{l}\text { 91002G2.1/Bill, 91002G2.1/Lut.9328, 91002G2.1/Lut.9381, Bill/Aspirant, Biscay/91002G2.1, } \\
\text { Bussard/Purdue4930//Bill, Dream/Lut.9329, Flair/96/101, Flair/Haldor, Lut.9329/Solist (2), Maverich/Savan- } \\
\text { nah, Sj993671/Bezenchiukskaya380, STH1096/96-101, STH1096/Nord34/106, STH1096/Sakwa, } \\
\text { Tarso/Bussard, }\end{array}$ & $\begin{array}{c}17 \\
(11.5 \%)\end{array}$ \\
\hline \multirow[t]{2}{*}{$50.1-100.0$} & $\begin{array}{l}\text { 91002G2.1/Lut.9381, Astron/Bill, Astron/Lut.9329, Bezenchiukskaya380/Rostovchanka2, Bill/91002G2.1, } \\
\text { Bill/Lut.9381, Bill/Residence, Biscay/91002G2.1 (4), Bussard/Purdue4930//Bill (3), Dream/Lut.9329 (2), } \\
\text { Eryth.1016-89/Lut.9313 (4), Flair/96/101, Flair/Bill (2), Flair/Haldor (4), Lut.9329/Solist (10), Lut.9392/Brandt } \\
\text { (6), Lut.9392/Kornett (4), Marabu/96.101, Marabu/Lut.9358, Marabu/Lut.96-3 (2), Maverich/CB9303 (3), } \\
\text { Maverich/Victo, Olivin/Bezenchiukskaya380, Pegassos/91002G2.1 (4), Residence/Baltimor, Residence/Bety, } \\
\text { Residence/Tommy (5), Sj993671/3/Tambor/Brigadier//Repear, STH1096/96/101 (3), STH1096/Ansgar (2), } \\
\text { STH1096/Bussard (4), STH1096/Flair (4), STH1096/Kris (2), STH1096/Lut.9358, STH1096/Sakwa (3), } \\
\text { STH1096/Strumok (2), STH1096/WTPT WM128 (3), STH1096/3/Astron//N96/st.290.19 (2), } \\
\text { Strumok/Lut.9329 (7), Strumok/Lut.9365 (5), Strumok/Lut.9392 (3), Tarso/Bussard (2), Tarso/Lut. 9358 (2), } \\
\text { Tarso/Lut.96-3 (2), Zentos/MV106-97, Zentos/Bezenchiukskaja380, Zolotava/Lut.9329 }\end{array}$ & $\begin{array}{c}120 \\
(81.1 \%)\end{array}$ \\
\hline & Average infection & 64.8 \\
\hline
\end{tabular}

* Number in brackets means how many lines with the same pedigree were tested.

Table 5

COMMON BUNT RESISTANCE OF ANCESTORS OF THE LEAST DAMAGED LINES

\begin{tabular}{|c|c|c|c|c|c|c|c|c|c|}
\hline \multirow[t]{2}{*}{ Genotype } & \multicolumn{4}{|c|}{ Bunt incidence, $\%$} & \multirow[t]{2}{*}{ Genotype } & \multicolumn{4}{|c|}{ Bunt incidence, $\%$} \\
\hline & $\%$ & year & $\%$ & year & & $\%$ & year & $\%$ & year \\
\hline $91002 \mathrm{G} 2.1$ & 14.6 & 2001 & 25.3 & 2007 & Lut.9381 & 19.3 & 2002 & 57.1 & 2003 \\
\hline $96 / 101$ & $*$ & $*$ & 31.7 & 2007 & Maverich & 35.9 & 2002 & 2.4 & 2003 \\
\hline Aspirant & $*$ & $*$ & 83.3 & 2001 & Miron.Ostistaya & 24.9 & 1993 & 82.5 & 1994 \\
\hline Bezench.380 & 20.3 & 1999 & 39.2 & 2007 & Miron.32 & $*$ & $*$ & 32.1 & 1999 \\
\hline Bill & 8.2 & 2003 & 17.2 & 2006 & Olivin & 29.3 & 2003 & 5.4 & 2004 \\
\hline Biscay & 31.5 & 2002 & 24.1 & 2003 & Pegassos & 26.6 & 1998 & 87.4 & 2001 \\
\hline Bold & 37.3 & 1999 & 57.4 & 2001 & Pesma & $*$ & $*$ & 21.2 & 2000 \\
\hline Bussard & 29.0 & 1997 & 48.1 & 2001 & Purdue4930 & 60.8 & 1994 & 26.9 & 1996 \\
\hline Cubus & 18.6 & 2003 & 7.6 & 2004 & Sakwa & $*$ & $*$ & 15.3 & 1998 \\
\hline Dream & 22.0 & 2001 & 21.9 & 2003 & Sj993671 & $*$ & $*$ & 41.6 & 2001 \\
\hline Flair & 75.9 & 2001 & 62.6 & 2002 & Soissons & $*$ & $*$ & 32.3 & 1997 \\
\hline Haldor & 4.4 & 2004 & 41.2 & 2007 & Solist & 21.7 & 2002 & 7.3 & 2003 \\
\hline Lasta & 30.3 & 2002 & 46.2 & 2003 & STH1096 & $*$ & $*$ & 45.7 & 2007 \\
\hline Lut.9313 & 16.7 & 2002 & 12.7 & 2007 & Strumok & $*$ & $*$ & 26.2 & 2007 \\
\hline Lut.9328 & $*$ & $*$ & 15.6 & 2000 & Tarso & 42.1 & 2001 & 25.4 & 2003 \\
\hline Lut.9329 & $*$ & $*$ & 10.2 & 2000 & Tommi & 15.0 & 2006 & 14.8 & 2007 \\
\hline Lut.9358 & 16.2 & 2002 & 11.3 & 2007 & Zolotava & $*$ & $*$ & 54.3 & 2007 \\
\hline
\end{tabular}

* cultivars in these years were not tested.

Average and maximum common bunt incidence in the following years: $2007-69.7,100 ; 2006-80.9,100 ; 2004-8.9,70.1 ; 2003-24.2,89.4 ; 2002-$ $30.8,91.7 ; 2001-40.7,100 ; 2000-17.7,69.4 ; 1999-22.9,88.9 ; 1998-6.8,38.1 ; 1997-21.8,69.8 ; 1996-19.1,76.5 ; 1994-46.9,100 ; 1993-22.3$, 74.6

sessed the same resistance genes because resistance of these lines was similar to that of the ancestors.

Different resistance of lines (from 1.9 up to $50 \%$ ) from crosses of very susceptible cultivars with cultivar Bill in pedigree suggests that this cultivar possesses more than one $B t$ gene or combination of major genes and Quantitative
Trait Loci (QTL). Cultivar Bill is of Danish origin and was derived from a multicross double haploid. Therefore, its pedigree remains unknown.

The line Residence/Tommi had the same resistance as cultivar Tommi. The resistance of cultivars Bill and Tommi but not the use of these cultivars in resistance breeding was de- 
scribed in other studies (Jahn et al., 2004; Dumalasova and Bartoš, 2006a; Vanova et al., 2006). Cultivar Tommi was developed in Germany from the cross Ralf/Astron//Haven and resistance was probably inherited from cultivar Ralf, because cultivars Astron and Haven were very susceptible in our trials.

The resistance cultivars Bill and Tommi to the most important wheat diseases was above average. The cultivars exhibited a high yield capacity, but these cultivars are generally susceptible to cold and are characterised by weak soil coverage (Anonymous, 2006). Therefore, these cultivars are suitable as resistance donors to common bunt but not for growing under organic conditions.

The lines from cross Flair/Lut.9329 inherited resistance from genotype Lut.9329 (infection $14.7 \%$ in 2000). Cultivar Flair was very susceptible - up to $75.9 \%$ in 2001. Also, many lines with genotype Lut.9329 were rather resistant. The other lines with Lut.9329 in pedigree (Dream/ Lut.9329, Strumok/Lut.9329, Lut.9329/Solist) might have inherited resistance from both parents, because both ancestors were in the same resistance group (up to $30 \%$ ). Genotype Lut.96-3/Bold might have inherited resistance from cultivar Bold, which showed some resistance in previous experiments (infection up to $57.4 \%$ in 2001). The reaction of this cultivar is mentioned in the publication of Dumalasova and Bartoš (2006b).

It is likely that the lines Strumok/Lut.9313, 91002G2.1/Lasta, Tarso/Bussard inherited resistance (infection up to $10 \%$ in 2007) from both ancestors, because both parental genotypes were more susceptible than lines developed.

Investigation of lines derived from crosses with cultivars possessing known resistance level shows what type of resistance these cultivars possess. If the derived lines were of similar resistance as one resistance donor, this suggests that the donors possess one major gene. If lines are more resistant, this suggests that donors possess two or more major genes and QTL's. Moreover, it shows the possibilities of pyramiding of genes with weak effectiveness to more effective combinations.

Investigation of different $T$. tritici populations has not been conducted in Lithuania. However, other European countries provide general information on the situation concerning virulence of $T$. tritici populations. In Northern Europe a high disease level occurs most frequently on cultivars carrying $B t 1, B t 2$, and $B t 7$; but virulence to $B t 1-B t 10$ has been described (Leijerstam, 1991). Till now only virulence to $B t 1, B t 2$, and $B t 7$ has been found in the Czech Republic (Blažkova and Bartoš, 2002). Virulence to Bt2 and Bt7 was found in Austria in 2005/2006 (Huber and Buerstmayr, 2006). Their results show that even the least effective genes $B t 2$ and $B t 7$ (13.6 and 38.0\%, while Heines VII, BtO, susceptible control had infection of $70.6 \%$ ) had some positive influence on resistance. Similar effectiveness of $B t$ genes was shown in Hungary in 1991-1997. Bt3 was relatively inefficient; infection on $B t$ genes was as follows: Bt1 - 32.7,
Bt2 - 25.5, Bt3 - 19.9, and Bt7 - 73.3\% (Veisz et al., 2000). Virulence to several other $B t$ genes was postulated in Germany. The effect of different proveniences of the inoculum on the disease incidence was recently demonstrated in trials by Wächter et al. (2005) and Koch et al. (2006) in which bunt inoculum from five different locations in Germany was applied.

Response of cultivars to common bunt in our tests in many cases agreed with the data obtained by foreign research elsewhere. However, some cultivars, for example Bold, Bussard, Lars, Cardos, Tommi, Tarso (Jahn et al., 2004; Dumalasova and Bartoš, 2006b) were shown to be more susceptible than in our investigations. The results suggest that if the $T$. tritici population used in our study consists of the race $\mathrm{T}-5$, which is the most widespread in Europe, then it is more aggressive than elsewhere. Possibly, the local population in Lithuania consists of other race/races.

Presently, the main problem for resistance breeding to Tilletia tritici is not deficiency of resistance genes in the total world wheat germplasm pool but deficiency of effective genes in modern cultivars with desirable agronomical traits for organic farming. The use of landraces or old cultivars is problematic because these genotypes are characterised as agronomically poor. For the Lithuanian climate, germplasm for example from the USA is relatively acceptable, but the main problem is low yielding capacity due to the short growing season; some lines are too susceptible to leaf diseases; weak stems are characteristic of many genotypes (Ruzgas and Liatukas, 2007). Genotypes from other continental countries such as Iran, Iraq, Afghanistan, and Turkey, which possess higher frequency of resistant genotypes (Bonman et al., 2006) in most cases are susceptible to cold and leaf diseases, are characterised by low yielding capacity, insufficient height and early ripening. Currently some resistant cultivars of European origin are available, e.g. cultivar Stava, which is resistant to the $T$. tritici and in its pedigree has PI 178383 with genes $B t 8, B t 9, B t 10$, but it is unknown which gene/genes was/were inherited. The resistance derived from PI 178383 (Bt8, Bt9, Bt10) remained effective in the USA for more than 20 years (Hoffmann, 1982). The effectiveness of these genes lasted for a period more than enough for search of new resistance donors and introduction of the new $B t$ genes into germplasm suitable for breeding. Much effort is expended in the USA to increase profitability of wheat through decreased inputs by growing resistant cultivars. Under relatively low pressure from chemical seed treatment and on the other hand under high selection pressure due to the use of resistant cultivars the effectiveness of these genes lasted for two decades. In contrast, the majority of wheat production areas are sown with chemically treated seeds in Europe due to intensive agriculture; and many cultivars are very susceptible to common bunt.

Under low chemical seed treatment and intensive use of resistant cultivars virulences formed slowly, over decades in the USA. In Europe wheat bunt has very few possibilities to occur in fields due to intensive use of chemical seed treat- 
ment. As general infection of common bunt in Europe is very low, this probably aids to avoid infections in organic farms. It is likely that strict regulations will enable successful use of resistant wheat cultivars in the area under organic agriculture, which accounts for a small share of the total wheat production area for decades ahead, especially, if cultivars with combinations of the new genes are used.

Seed quality is a central issue in organically oriented farming systems. Although all lines were infected, the lines with ear infection below $10 \%$ provide a chance to minimise the risk of bunt infection in organic wheat production in Lithuania. Cultivars damaged more than $10 \%$ under conditions favourable for disease cannot be recommended for organic production without seed treatment with organic materials or physical treatment. The most promising lines can be used for further evaluation for suitability for organic growing or for resistance breeding as parental forms with known resistance and complex of desirable agronomic traits.

\section{ACKNOWLEDGEMENTS}

This research was supported by the Lithuanian State Science and Studies Foundation, project N-07004 (KVIETPOLIMER) and research programme "Genofondas" initiated by the Lithuanian Ministry of Education and Science.

\section{REFERENCES}

Anonymous (2006). Bundesssortenamt. Beschreibende Sortenliste 2006. Hannover GmbH. 271 p.

Blažkova, V., Bartoš, P. (2002). Virulence pattern of European bunt samples (Tilletia tritici and T. leavis) and sources of resistance. Cereal Res. Commun., 30(3/4), 335-342.

Bonman, J.M., Bockelman, H.E., Goates, B.J., Don Obert, E., McGuire, P.E., Qualset, C.O., Hijmans, R.J. (2006). Geographic distribution of common and dwarf bunt resistance in landraces of Triticum aestivum subsp. aestivum. Crop Sci., 46, 1622-1629.

Borgen, A., Davanlou, M. (2000). Biological control of common bunt (Tilletia tritici) in organic agriculture. J. Plant Dis. Protect., 107, 74-80.

Dumalasova, V., Bartoš, P. (2006a). Reaction of winter wheat cultivars registered in the Czech Republic to common bunt Tilletia tritici (Bjerk.) and T. leavis Kühn. Cereal Res. Commun. 34, 1275-1282.
Dumalasova, V., Bartoš, P. (2006b). Resistance of winter wheat cultivars to common bunt, Tilletia tritici (Bjerk.) Wint. and T. leavis Kühn. J. Plant Dis. Protect., 113, 159-163.

Gaudet, D.A., Puchalski, B.J. (1990). Influence of planting dates on the aggressiveness of common bunt races (Tilletia tritici and T. laevis) to Canadian spring wheat cultivars. Canad. J. Plant Pathol., 12, 204-208.

Gaudet, D. A., Puchalski, B. J., Entz, T. (1994). Effects of seeding date and cultivar susceptibility on effectiveness of carbathiin for control of common bunt (Tilletia tritici and T. laevis) in winter wheat in southern Alberta. Plant Pathol., 16, 304-310.

Hoffman, J. A. (1982). Bunt of wheat. Plant Disease, 66(11), 979-986.

Hubert, K., Buerstmayr, H. (2006). Development of methods for bunt resistance breeding for organic farming. Czech J. Genet. Plant Breed., 42 (Spec. Iss.), 66-71.

Jahn, H., Koch, E., Wätchter, R., Waldow, F. (2004). Saatgutgesundheit im ökologischen Landbau - Schwerpunkt weizensteinbrand (Tilletia caries). In: Ressortforschung für den Ökologischen Landbau, 2003, Statusseminar, 5. Märtz, BBA (pp. 7-16). Kleinmachnow.

Johnsson, L. (1992). Climate factors influencing attack of common bunt (Tilletia caries (DC) Tul.) in winter wheat in 1940-1988 in Sweden. J. Plant Dis. Protect. 99, 21-28.

Leijerstam, B. (1991) Virulence patterns in bunt of wheat. Sveriges Utsädesförenings Tidskrift., 101, 89-93.

Koch, E., Wächter R., Spiess, H. (2006). Characterization of resistance of wheat varieties and breeding lines against common bunt (Tilletia tritici) and dwarf bunt (T. controversa). Czech J. Genet. Plant Breed., 42 (Spec. Iss.), 32 .

Martynov, S.P., Dobrotvorskaya, T.V., Sorokin, O.D. (2004). Comparative genealogical analysis of the resistance of winter wheat to common bunt. Russ. J. Gen., 40, 410-424.

Petrenkova, V.P., Rabynivich, S.V., Chernyaeva, I.M. and Chernobai, L.M. (2005). Identifying sources and donors of genes for resistance to covered smut of winter wheat in Ukraine. Ann. Wheat Newsletter, 51, 169-170.

Ruzgas, V., Liatukas, Ž. (2007). Investigation and utilization of winter wheat germplasm from dry climate country. In: Plant Genetic Resources and Their Exploitation in the Plant Breeding for Food and Agriculture. Book of Abstracts. $18^{\text {th }}$ Eucarpia genetic resources section meeting, 23-26 May 2007 (pp. 170-171). Pieštany, Slovak Republic.

Szunics, L. (1990). Data on common bunt infection in wheat varieties. Növenytermeles, 39, 297-304.

Vanova, M., Matušinsky, P., Benada, J. (2006). Survey of incidence of bunts (Tilletia caries and Tiletia controversa) in the Czech Republic and susceptibility of winter wheat cultivars. Plant Protect Sci., 42, 21-25.

Veisz, O., Szunics, Lu., Szunics, L. (2000). Effect of common bunt on the frost resistance and winter hardiness of wheat (Triticum aestivum L.) lines containing Bt genes. Euphytica, 114, 159-164.

Wächter, R., Wolf, G., Koch, E. (2005). Characterisierung der resistenz von winterweizensortes gegenüber steinbrand (Tilletia caries). In: 8. Wissenschaftstagung Ökologischer Landau, Kassel, 1.-4. März 2005 (pp. 121-124). Kassel: Kassel University Press.

Received 16 September 2008

\section{LIETUVAS LABĀKO ZIEMAS KVIEŠU SELEKCIJAS LĪNIJU REAKCIJA UZ CIETO MELNPLAUKU}

2006.-2007. g. pārbaudīta Lietuvas Lauksaimniecības institūtā izveidoto ziemas kviešu selekcijas līniju izturība pret cieto melnplauku. Augstais infekcijas līmenis ḷāva atlasīt izturīgas līnijas, perspektīvas kā konvencionālai, tā bioloǵiskai lauksaimniecībai. 